\title{
Colorectal Cancer in Patients Under Close Colonoscopic Surveillance
}

\author{
DOUGLAS J. ROBERTSON, ${ }^{,}{ }^{\ddagger}$ E. ROBERT GREENBERG, ${ }^{\ddagger}, \S, \| \operatorname{MICHAEL~BEACH,~}$, , \\ ROBERT S. SANDLER, ${ }^{\#}$ DENNIS AHNEN, ${ }^{* *},{ }^{\ddagger}$ ROBERT W. HAILE, $\$ §$ CAROL A. BURKE, \|\| \\ DALE C. SNOVER, "था ROBERT S. BRESALIER, ${ }^{\# \# ~ G A I L ~ M C K E O W N-E Y S S E N, ~} * * *$ JACK S. MANDEL, ${ }^{\neq \neq}$

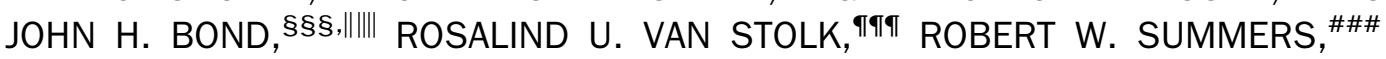 \\ RICHARD ROTHSTEIN, ${ }^{\ddagger}$ TIMOTHY R. CHURCH,**** BERNARD F. COLE,,$\|$ TIM BYERS, $\$ \S$ \\ LEILA MOTT, $\$$ and JOHN A. BARON ${ }^{\ddagger, \S, \|}$ \\ *VA Medical Center, White River Junction, Vermont; ${ }^{\dagger}$ Department of Medicine, ${ }^{\S}$ Department of Community and Family Medicine, "Norris \\ Cotton Cancer Center, and "Department of Anesthesia, Dartmouth-Hitchcock Medical Center, Lebanon, New Hampshire; "Department of \\ Medicine, University of North Carolina School of Medicine, Chapel Hill, North Carolina; **VA Medical Center, Denver, Colorado; \\ ${ }^{*}$ Department of Medicine, University of Colorado School of Medicine, Denver, Colorado; ${ }^{\S \S}$ Department of Preventive Medicine, University of \\ Southern California School of Medicine, Los Angeles, California; "ll|Department of Gastroenterology, Cleveland Clinic Foundation, Cleveland, \\ Ohio; ${ }^{\Upsilon \Upsilon}$ Department of Pathology, Fairview Southdale Hospital, Minneapolis, Minnesota; \#\#Department of Gastrointestinal Medicine and \\ Nutrition, University of Texas MD Anderson Cancer Center, Houston, Texas; ***Department of Public Health Sciences, University of Toronto, \\ Toronto, Ontario, Canada; ${ }^{\ddagger \dagger}$ Rollins School of Public Health, Emory University, Atlanta, Georgia; ${ }^{\S \S}$ Department of Medicine, University of

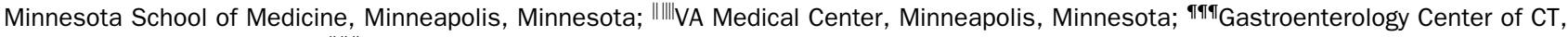 \\ P.C., Hamden, Connecticut; \#\#\#Department of Internal Medicine, University of lowa Carver College of Medicine, lowa City, Iowa;

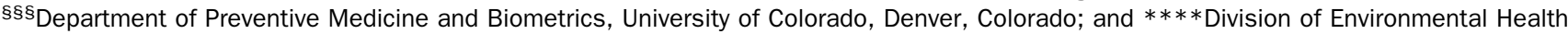 \\ Sciences, School of Public Health, University of Minnesota, Minneapolis, Minnesota
}

Background \& Aims: Colonoscopic polypectomy is considered effective for preventing colorectal cancer (CRC), but the incidence of cancer in patients under colonoscopic surveillance has rarely been investigated. We determined the incidence of CRC in patients under colonoscopic surveillance and examined the circumstances and risk factors for CRC and adenoma with high-grade dysplasia. Methods: Patients were drawn from 3 adenoma chemoprevention trials. All underwent baseline colonoscopy with removal of at least one adenoma and were deemed free of remaining lesions. We identified patients subsequently diagnosed with invasive cancer or adenoma with high-grade dysplasia. The timing, location, and outcome of all cases of cancer and high-grade dysplasia identified are described and risks associated with their development explored. Results: CRC was diagnosed in 19 of the 2915 patients over a mean follow-up of 3.7 years (incidence, 1.74 cancers/ 1000 person-years). The cancers were located in all regions of the colon; 10 were at or proximal to the hepatic flexure. Although most of the cancers (84\%) were of early stage, 2 participants died of CRC. Seven patients were diagnosed with adenoma with high-grade dysplasia during follow-up. Older patients and those with a history of more adenomas were at higher risk of being diagnosed with invasive cancer or adenoma with highgrade dysplasia. Conclusions: CRC is diagnosed in a clinically important proportion of patients following com- plete colonoscopy and polypectomy. More precise and representative estimates of CRC incidence and death among patients undergoing surveillance examinations are needed.

ndoscopic removal of adenomas is associated with a $\mathbf{E}_{\text {significant reduction in the risk of colorectal can- }}$ cer, ${ }^{1-3}$ although the size of the benefit is not clear. ${ }^{4,5}$ Accurate data regarding the magnitude of the risk reduction are important so that the medical community can determine the best approach to colorectal cancer screening ${ }^{6-8}$ and so that patients can decide whether to undergo screening. Large case-control studies ${ }^{1,2}$ indicate that sigmoidoscopy or colonoscopy results in about a $50 \%$ reduction in the incidence of colorectal cancer in the examined portions of the bowel. The investigators of the National Polyp Study (NPS) estimated a larger reduction in risk (up to $90 \%$ ) based on an analysis ${ }^{3}$ of patients randomized to 2 different schedules of periodic surveillance colonoscopy. However, both the NPS anal-

\footnotetext{
Abbreviations used in this paper: $\mathrm{Cl}$, confidence interval; NPS, National Polyp Study; SEER, Surveillance, Epidemiology, and End Results. (C) $\mathbf{2 0 0 5}$ by the American Gastroenterological Association 0016-5085/05/\$30.00 doi:10.1053/j.gastro.2005.05.012
} 
ysis and the case-control studies entailed a number of methodological assumptions that could not be validated directly. The NPS investigators used external controls to assess efficacy of polypectomy. In the case-control studies of sigmoidoscopy, there remains the possibility that differences between populations that choose to undergo screening and those who do not might account for some of the risk reduction seen. Therefore, estimates of efficacy derived from these studies are uncertain. 4,5

To describe the risk of colorectal cancer occurring in the course of colonoscopic surveillance, we determined the frequency of invasive cancer and adenomas with high-grade dysplasia among patients followed up in 3 randomized trials of colorectal adenoma chemoprevention.

\section{Materials and Methods}

We have previously reported the essential features of the design and principal findings of the 3 multicenter randomized trials that form the basis for the current analyses. ${ }^{9-11}$ Institutional review board approval to perform the trials and collect the information that is reported herein was obtained from all participating centers in each study. Briefly, patients qualified for study by having at least one histologically documented large bowel adenoma of any size removed shortly before study entry. Within 3 months of study enrollment, each had undergone a complete (ie, to the cecum) colonoscopic "clearing" examination, with the attending endoscopist attesting that the entire colorectal mucosa was adequately visualized and that no known colorectal polyps remained after the procedure. Patients were excluded if they had familial polyposis, invasive colorectal cancer, malabsorption syndromes, or conditions that might be worsened by the study agents.

We obtained information from participants at enrollment regarding their history of adenomas, lifestyle habits, and family history (first-degree family members) of colorectal polyps and cancer. Follow-up colonoscopies for patients in the first 2 trials were scheduled about 1 and 4 years after the clearing examination. Patients enrolled in the third trial were scheduled for surveillance colonoscopy about 3 years after the clearing examination. In each of the studies, the location and size of all polyps removed from the bowel were noted, and tissue specimens were sent for central histopathology review.

The same study pathologist (D.C.S.) reviewed all follow-up tissue specimens for the 3 trials to determine whether or not neoplasia was present and, if so, whether there was invasive cancer or high-grade dysplasia (formerly referred to as carcinoma in situ). Based on these determinations, we identified all patients diagnosed with either cancer or high-grade dysplasia and obtained supportive documentation (eg, procedure notes, operative reports) from their medical records. A single investigator reviewed all relevant clinical information to confirm the diagnosis and to record the treatment of the cancer and the outcome. For invasive cancers, tumor size and nodal status were abstracted from the local pathology report and stage was determined according to the criteria of the American Joint Committee on Cancer. ${ }^{12}$

To determine incidence rates, we computed person-years at risk (ie, time under active surveillance) for each patient based on the interval between the date of the "clearing" colonoscopy and the earliest of the following end points: termination of the treatment phase of the study, death, loss to follow-up, or the occurrence of high-grade dysplasia or cancer. The crude incidence rate of invasive cancer was computed as the observed number of cancers divided by the total person-years of surveillance. To estimate confidence limits for the incidence rates, we assumed the numerator of the rate to be a Poisson variable and calculated confidence intervals (CIs) by the exact method. ${ }^{13}$ Rates were compared using a conditional test based on the exact binomial distribution. ${ }^{14}$ We calculated a standardized incidence ratio to compare the cancer incidence rates in our study population with those obtained from the population covered by the Surveillance, Epidemiology, and End Results (SEER) program (1984-2000), with standardization for sex, age (5-year age groups), race (white, black), and year of study (annual). For subjects who were at risk in 2001 or later, SEER data were not available so rates from 2000 were used. Wilcoxon rank sum test for continuous variables and Fisher exact test for categorical variables were used to assess the characteristics of patients that were associated with the subsequent occurrence of cancer and high-grade dysplasia.

\section{Results}

A total of 2915 patients were randomized in the 3 trials. The characteristics of the participants differed only moderately among studies, and overall $71 \%$ were men, $85 \%$ were white, and the average age was 59.7 years (Table 1). Colonoscopic follow-up was essentially complete; $97 \%(\mathrm{n}=2836)$ of subjects had at least one examination after the qualifying colonoscopy, and in 91\% ( $\mathrm{n}=2664)$ follow-up ended with a year-3 (third trial) or year-4 colonoscopy (trials 1 and 2) as per protocol. Most of the 79 subjects who did not complete the anticipated colonoscopic follow-up had died from causes other than colorectal cancer $(n=40)$ or had severe illness ( $\mathrm{n}=10$ ) precluding follow-up endoscopy. The mean follow-up time after qualifying colonoscopy was 3.7 years, during which 26 patients $(0.9 \%)$ were found to have either an invasive cancer (19) or adenoma with high-grade dysplasia (7).

Of the 19 cases of cancer, 4 were found because of patient symptoms and 15 during a surveillance colonoscopy. One patient had a colorectal cancer detected because he requested a colonoscopy after being diagnosed with prostate cancer (Table 2). The cancers were located in all regions of the colon; 10 were at or proximal to the hepatic flexure. In 5 cases, a large $(\geq 1.0 \mathrm{~cm})$ adenoma 
Table 1. Study Characteristics of the 3 Clinical Trials

\begin{tabular}{|c|c|c|c|c|}
\hline & $\begin{array}{l}\text { Antioxidant Polyp } \\
\text { Prevention Study }\end{array}$ & $\begin{array}{l}\text { Calcium Polyp } \\
\text { Prevention Study }\end{array}$ & $\begin{array}{l}\text { Aspirin/Folate Polyp } \\
\text { Prevention Study }\end{array}$ & Total \\
\hline \multicolumn{5}{|l|}{ Entry characteristics } \\
\hline No. randomized & 864 & 930 & 1121 & 2915 \\
\hline Age, $y($ mean $\pm \mathrm{SD})$ & $61.2( \pm 8.3)$ & $61.0( \pm 9.1)$ & $57.5( \pm 9.6)$ & $59.7( \pm 9.3)$ \\
\hline Sex (\% male) & 79.2 & 72.3 & 63.5 & 70.9 \\
\hline Race (\% nonwhite) & 14.8 & 15.0 & 14.5 & 14.7 \\
\hline $\begin{array}{l}\text { Subjects with at least one adenoma at qualifying } \\
\text { examination (\%) }\end{array}$ & 100 & 100 & 100 & 100 \\
\hline $\begin{array}{l}\text { Subjects with at least one adenoma } \geq 1 \mathrm{~cm} \text { at } \\
\text { qualifying examination (\%) }\end{array}$ & 40.3 & 29.1 & 22.8 & 30.0 \\
\hline $\begin{array}{l}\text { Subjects with a history of adenoma before qualifying } \\
\text { examination (\%) }\end{array}$ & 24.0 & 21.6 & 30.3 & 25.6 \\
\hline \multicolumn{5}{|l|}{ Follow-up events } \\
\hline Mean follow-up, $y( \pm \mathrm{SE})$ & $4.0( \pm 0.8)$ & $4.1( \pm 0.7)$ & $3.2( \pm 0.6)$ & $3.7( \pm 0.8)$ \\
\hline Subjects with at least one adenoma (\%) & 51.6 & 46.9 & 43.5 & 47.0 \\
\hline No. of subjects with adenoma with high-grade dysplasia & 5 & 2 & 0 & 7 \\
\hline No. of subjects with invasive cancer & 5 & 8 & 6 & 19 \\
\hline
\end{tabular}

had been removed from the same segment of colon at the time of the most recent prior colonoscopy. Eleven patients had stage I cancers, 5 stage II, and 3 stage III, 2 of whom subsequently have died of colorectal cancer.

The overall incidence of colorectal cancer among all patients was 1.74 (95\% CI, 1.05-2.72) per 1000 personyears of follow-up. The rate of cancer development was higher in men than in women (2.19 vs 0.64 per 1000 person-years), but this difference did not reach statistical significance $(P=.08)$. The subgroup of 2154 patients without a history of adenoma before the qualifying examination had an incidence rate of 1.35 (95\% CI, 0.682.42) per 1000 person-years of follow-up. The incidence of colorectal cancer was higher $(2.88$ [95\% CI, 1.245.67) per 1000 person-years) in the 761 patients with a prior history of adenoma before the qualifying examination, but this was not statistically different from that for those without a prior history $(P=.11)$. Overall, the incidence of a cancer diagnosis was very similar to that expected from SEER data (standardized incidence ratio, 0.98; 95\% CI, 0.63-1.54).

We calculated separate colorectal cancer incidence rates for the first year of follow-up and the subsequent 3 years of follow-up among the 1794 patients who had been scheduled for 2 surveillance colonoscopies (ie, participants in the first 2 chemoprevention trials). The incidence was $3.79(95 \% \mathrm{CI}, 1.63-7.47)$ per 1000 person-years for the first follow-up interval (clearing examination up to and including the year-1 examination) and 0.96 (95\% CI, 0.31-2.24) per 1000 person-years for the second interval (year-1 examination up to and including the year-4 examination). The rates of cancer detection in these 2 follow-up periods were significantly different $(P$ $=.01)$.
Seven adenomas with high-grade dysplasia were found in 7 study subjects (Table 3). All were identified during a surveillance colonoscopy, and 6 of the 7 were found at the first scheduled colonoscopy (an interval of 12-18 months after the clearing examination). Six of the adenomas were $>1 \mathrm{~cm}$ in diameter, and the other was 0.7 $\mathrm{cm}$. Five of the lesions were judged to have tubulovillous histology, and the other 2 were simple tubular adenomas. Three of the lesions (all large and sessile) were surgically resected to assure complete removal.

The 26 patients diagnosed with an advanced neoplasm (cancer or adenoma with high-grade dysplasia) were older than those without such findings (mean age, 65.5 vs 59.6 years; $P=.001$ ) and had a greater mean number of prior lifetime adenomas ( 4.3 vs $2.5 ; P=.02)$. Patients who had a large $(\geq 1.0 \mathrm{~cm})$ adenoma at the time they qualified for the trials seemed more likely to be diagnosed with an advanced neoplasm than were those who had smaller adenomas ( $1.24 \%$ vs $0.74 \% ; P=.20)$, and men seemed more likely than women to have an advanced neoplasm (1.06\% vs $0.5 \% ; P=.08)$, although neither finding was statistically significant. Race, cigarette smoking history, and family history of colorectal cancer or adenoma were not related to risk of an advanced neoplasm (Table 4).

\section{Discussion}

In our trials, we followed up 2915 patients with adenomas using surveillance protocols that called for complete colonoscopic examination; 26 of these patients were diagnosed with invasive colorectal cancer or highgrade dysplasia. Of the 19 cancers identified, 8 were stage II or greater; 2 of these cancers ultimately caused the death of the patients. Fifteen $(79 \%)$ of the cancers 
Table 2. Description of Patients Diagnosed With Invasive Cancer During the Follow-up Period

\begin{tabular}{|c|c|c|c|c|c|c|}
\hline \multicolumn{5}{|c|}{ Colonoscopy identifying cancer } & \multicolumn{2}{|c|}{$\begin{array}{l}\text { Colonoscopy immediately before } \\
\text { examination identifying cancer }\end{array}$} \\
\hline Age/sex/race & Indication & $\begin{array}{c}\text { Months } \\
\text { since entry } \\
\text { examination }\end{array}$ & Size/shape/location of lesion & Stage & $\begin{array}{l}\text { No. of adenoma } \\
\text { (largest } \\
\text { adenoma) }\end{array}$ & $\begin{array}{l}\text { Adenoma in same } \\
\text { segment as cancer }\end{array}$ \\
\hline $74 / \mathrm{M} / \mathrm{W}$ & "Blood in stool" & 6.4 & $4.5 \mathrm{~cm} /$ sessile $/$ cecum & T1 No/stage I & $1(0.9 \mathrm{~cm})$ & No \\
\hline 71/M/W & $\begin{array}{l}\text { Surveillance/ } \\
1 \text { year }\end{array}$ & 12.3 & $1.2 \mathrm{~cm} /$ pedunculated/sigmoid & T1 N1/stage III & $3(1.0 \mathrm{~cm})$ & $1.0 \mathrm{~cm}$ pedunculated \\
\hline $58 / \mathrm{M} / \mathrm{H}$ & $\begin{array}{l}\text { Surveillance/ } \\
1 \text { year }\end{array}$ & 12.4 & $\begin{array}{l}2.5 \mathrm{~cm} / \text { sessile/ascending } \\
\text { colon }\end{array}$ & T2 No/stage I & $2(1.2 \mathrm{~cm})$ & $1.2 \mathrm{~cm}$ sessile \\
\hline $68 / \mathrm{M} / \mathrm{W}$ & $\begin{array}{l}\text { Surveillance/ } \\
1 \text { year }\end{array}$ & 12.4 & $\begin{array}{l}1.8 \mathrm{~cm} / \text { sessile } / \text { hepatic } \\
\text { flexure }\end{array}$ & $\begin{array}{l}\text { Endoscopic } \\
\text { resection } \\
\text { only }\end{array}$ & $3(1.0 \mathrm{~cm})$ & No \\
\hline $66 / \mathrm{M} / \mathrm{W}$ & $\begin{array}{l}\text { Surveillance/ } \\
1 \text { year }\end{array}$ & 13.0 & $\begin{array}{l}0.3 \mathrm{~cm} / \text { sessile } / \text { descending } \\
\text { colon }\end{array}$ & T1 N0/stage I & $2(2.5 \mathrm{~cm})$ & $2.5 \mathrm{~cm}$ pedunculated \\
\hline $66 / \mathrm{M} / \mathrm{W}$ & $\begin{array}{l}\text { Surveillance/ } \\
1 \text { year }\end{array}$ & 15.2 & $>0.5 \mathrm{~cm} / \mathrm{sessile} / \mathrm{rectum}{ }^{a}$ & T3 NO/stage II & $3(1.2 \mathrm{~cm})$ & $1.0 \mathrm{~cm}$ sessile \\
\hline $60 / \mathrm{M} / \mathrm{NA}$ & $\begin{array}{l}\text { Surveillance/ } \\
1 \text { year }\end{array}$ & 24.1 & $2 \mathrm{~cm} / \mathrm{sessile} /$ ascending colon & T1 N0/stage I & $4(2.5 \mathrm{~cm})$ & No \\
\hline $57 / M / W$ & Patient request & 26.0 & $1.5 \mathrm{~cm} /$ pedunculated/cecum & T3 NO/stage II & $1(0.3 \mathrm{~cm})$ & No \\
\hline 72/M/W & Anemia & 26.2 & $\begin{array}{l}\text { Circumferential } \\
\text { mass/ascending colon }\end{array}$ & T3 NO/stage II & $1(0.4 \mathrm{~cm})$ & No \\
\hline $54 / F / B$ & $\begin{array}{l}\text { Surveillance/ } \\
3 \text { years }\end{array}$ & 35.2 & $2.5 \mathrm{~cm} / \mathrm{sessile} /$ rectosigmoid & T2 N1/stage III & $1(1.2 \mathrm{~cm})$ & $1.2 \mathrm{~cm}$ pedunculated \\
\hline $47 / M / W$ & $\begin{array}{l}\text { Surveillance/ } \\
3 \text { years }\end{array}$ & 36.3 & $3 \mathrm{~cm} /$ sessile/ascending colon & T2 No/stage I & $1(0.7 \mathrm{~cm})$ & No \\
\hline $65 / M / W$ & $\begin{array}{l}\text { Surveillance/ } \\
3 \text { years }\end{array}$ & 38.8 & $\begin{array}{l}1.5 \mathrm{~cm} / \text { sessile/ascending } \\
\text { colon }\end{array}$ & T1 N0/stage I & $1(0.2 \mathrm{~cm})$ & $0.2 \mathrm{~cm}$ sessile \\
\hline $64 / \mathrm{M} / \mathrm{W}$ & $\begin{array}{l}\text { Surveillance/ } \\
3 \text { years }\end{array}$ & 41.2 & $1.5 \mathrm{~cm} / \mathrm{sessile} /$ rectum & T1 N0/stage I & $1(2.0 \mathrm{~cm})$ & No \\
\hline 71/M/W & $\begin{array}{l}\text { Weight loss, } \\
\text { hematochezia }\end{array}$ & 42 & $\begin{array}{l}1.0 \mathrm{~cm} / \mathrm{sessile} / \text { hepatic } \\
\text { flexure }\end{array}$ & T3 NO/stage $\|^{b}$ & None & No \\
\hline $67 / M / W$ & "Bloody stools" & 43.1 & $6 \mathrm{~cm} / \mathrm{sessile} / \mathrm{rectum}$ & T2 No/stage I & None & No \\
\hline 70/M/W & $\begin{array}{l}\text { Surveillance/ } \\
4 \text { years }\end{array}$ & 46.5 & $2 \mathrm{~cm} / \mathrm{sessile} /$ sigmoid & T1 N0/stage I & $5(0.5 \mathrm{~cm})$ & $0.4 \mathrm{~cm}$ sessile \\
\hline $67 / F / B$ & $\begin{array}{l}\text { Surveillance/ } \\
4 \text { years }\end{array}$ & 47.7 & $\begin{array}{l}3-5 \mathrm{~cm} / \text { sessile/ascending } \\
\text { colon }\end{array}$ & $\begin{array}{l}\text { T3 N2/stage } \\
\text { III }^{b}\end{array}$ & $3(0.3 \mathrm{~cm})$ & No \\
\hline $58 / \mathrm{M} / \mathrm{W}$ & $\begin{array}{l}\text { Surveillance/ } \\
4 \text { years }\end{array}$ & 51.7 & “Large"/splenic flexure & T2 N0/stage I & None & No \\
\hline 73/M/W & $\begin{array}{l}\text { Surveillance/ } \\
4 \text { years }\end{array}$ & 54 & $2 \times 3 \mathrm{~cm} /$ sessile $/$ rectum & T3 NO/stage II & None & No \\
\hline
\end{tabular}

M, male; W, white; H, Hispanic; NA, Native American; F, female; B, black.

aExact size not mentioned in endoscopy report.

${ }^{b}$ Died of colorectal cancer.

were found during a surveillance examination and were apparently asymptomatic. Older age and greater number of lifetime adenomas were significantly associated with diagnosis of advanced lesions.

The rate of cancer diagnosis that we observed $(1.74$ cancers/1000 person-years) is similar to that found in several other clinical trials that involved colonoscopic follow-up of patients with resected colorectal adenomas. The Polyp Prevention Trial investigators found 13 cancers among 2079 patients followed up for a mean of 2.79 years (2.2 cancers/1000 person-years). ${ }^{15}$ In the Wheat Bran Fiber Trial, 9 cancers developed among 1303 patients with a median follow-up of 35 months (2.4 can- cers/1000 person-years). ${ }^{16}$ The Funen Adenoma Follow-up Study investigators examined cancer incidence in a randomized study of surveillance intervals among 1056 patients; 10 cancers developed during 4540 person-years of follow up (2.2 cancers/1000 person-years). ${ }^{17}$ The effects of calcium and aspirin on reducing polyp recurrence in 2 of our 3 studies may partly explain why we found a slightly lower incidence rate of cancer in our population than that reported from other prevention studies in which the interventions were not effective.

In contrast, the cancer incidence rate in our population was higher than that reported from the NPS (0.6 cancers/ 1000 person-years). Several factors may explain this 
Table 3. Description of Patients Diagnosed With Adenomas With High-Grade Dysplasia During the Follow-up Period

\begin{tabular}{|c|c|c|c|c|c|c|}
\hline \multicolumn{5}{|c|}{ Colonoscopy identifying adenoma with high-grade dysplasia } & \multicolumn{2}{|c|}{$\begin{array}{l}\text { Colonoscopy immediately before } \\
\text { examination identifying adenoma with } \\
\text { high-grade dysplasia }\end{array}$} \\
\hline Age/sex/race & Indication & $\begin{array}{l}\text { Months } \\
\text { since entry } \\
\text { examination }\end{array}$ & Size/shape/location of lesion & Treatment & $\begin{array}{l}\text { No. of adenoma } \\
\text { (largest } \\
\text { adenoma) }\end{array}$ & $\begin{array}{l}\text { Adenoma in same } \\
\text { segment as cancer }\end{array}$ \\
\hline 71/M/W & Surveillance & 17.6 & $0.7 \mathrm{~cm} /$ pedunculated $/$ sigmoid & Endoscopic removal & $3(0.6 \mathrm{~cm})$ & $\begin{array}{l}0.6 \mathrm{~cm}, 0.5 \mathrm{~cm} \text {, and } \\
0.3 \mathrm{~cm} \text {, all sessile }\end{array}$ \\
\hline $66 / \mathrm{M} / \mathrm{W}$ & Surveillance & 15.4 & $\begin{array}{l}1.5 \mathrm{~cm} \times 2.5 \mathrm{~cm} / \text { sessile } / \\
\text { rectal }\end{array}$ & Transanal resection & $3(1.2 \mathrm{~cm})$ & $1.2 \mathrm{~cm}$ sessile \\
\hline $72 / \mathrm{M} / \mathrm{W}$ & Surveillance & 12.0 & $\begin{array}{l}1.2 \mathrm{~cm} / \text { sessile/ascending } \\
\text { colon }\end{array}$ & Endoscopic removal & $2(0.6 \mathrm{~cm})$ & No \\
\hline $69 / \mathrm{F} / \mathrm{B}$ & Surveillance & 14.0 & $\begin{array}{l}2.0 \mathrm{~cm} / \text { pedunculated/ } \\
\text { rectal }\end{array}$ & Endoscopic removal & $4(0.3 \mathrm{~cm})$ & No \\
\hline $63 / F / W$ & Surveillance & 13.0 & $3.0 \mathrm{~cm} /$ sessile $/$ cecum & Cecal resection & $1(1.0 \mathrm{~cm})$ & $1 \mathrm{~cm}$ sessile \\
\hline $68 / \mathrm{M} / \mathrm{W}$ & Surveillance & 11.8 & $\begin{array}{l}1.5 \mathrm{~cm} / \text { pedunculated/ } \\
\text { ascending colon }\end{array}$ & Endoscopic removal & $2(0.5 \mathrm{~cm})$ & No \\
\hline $66 / \mathrm{M} / \mathrm{W}$ & Surveillance & 45.1 & $\begin{array}{l}5.0 \mathrm{~cm} / \mathrm{sessile} / \text { transverse } \\
\text { colon }\end{array}$ & Hemicolectomy & $2(0.5 \mathrm{~cm})$ & No \\
\hline
\end{tabular}

M, male; $\mathrm{W}$, white; F, female; B, black.

higher rate. First, the NPS only enrolled subjects after first presentation with adenoma and therefore focused on a lower-risk group. Cancer incidence was higher for our subjects with a history of adenomas; however, even when we considered only subjects presenting with a first adenoma, our cancer incidence rate remained more than twice that in the NPS. A second explanation as to why we observed a higher rate of colorectal cancer diagnosis is that our study entailed more complete colonoscopic follow-up. Nearly all of our subjects had at least one surveillance colonoscopy performed during follow-up, and we defined the denominator for our incidence esti- mates based on the interval between the clearing examination and the date of the last colonoscopy for each patient. Thus, our study protocol facilitated the detection of small asymptomatic cancers. By contrast, the NPS rates were based on the entire period of follow-up contact for each patient, and much of this time occurred after the last colonoscopy. For example, in the NPS, $20 \%$ of patients received no scheduled follow-up colonoscopy, although they remained under study and had their follow-up time included in the estimates of incidence rate. A similar phenomenon may account for the low cancer incidence reported from an Italian study ${ }^{18}$ in which 6

Table 4. Association of Baseline Characteristics With High-Grade Dysplasia and Cancer

\begin{tabular}{|c|c|c|c|c|}
\hline \multirow[b]{2}{*}{ Baseline variable } & \multirow[b]{2}{*}{$n *$} & \multicolumn{2}{|c|}{$\begin{array}{l}\text { Invasive cancer or high-grade } \\
\text { dysplasia }\end{array}$} & \multirow[b]{2}{*}{$P$} \\
\hline & & No & Yes $(n=26)$ & \\
\hline Mean age, $y( \pm \mathrm{SD})$ & 2915 & $59.6( \pm 9.3)$ & $65.5( \pm 7.0)$ & .001 \\
\hline $\operatorname{Sex}(\%)$ & 2915 & & & .08 \\
\hline Male & & $2046(70.8)$ & $22(84.6)$ & \\
\hline Female & & $843(29.2)$ & $4(15.4)$ & \\
\hline Race (\%) & 2912 & & & .57 \\
\hline White & & $2461(85.3)$ & $21(80.8)$ & \\
\hline Other & & 425 (14.7) & $5(19.2)$ & \\
\hline Smoking status (\%) & 2891 & & & .31 \\
\hline Never & & $1048(36.6)$ & $7(28.0)$ & \\
\hline Former & & $1287(44.9)$ & $15(60.0)$ & \\
\hline Current & & $531(18.5)$ & $3(12.0)$ & \\
\hline Family history of cancer (\%) & 2571 & $695(27.2)$ & $5(25.0)$ & 1.00 \\
\hline Family history of colorectal polyps (\%) & 2571 & $530(20.8)$ & $5(25.0)$ & 1.00 \\
\hline Mean no. of adenomas at qualifying examination $( \pm S D)$ & 2889 & $1.8( \pm 1.3)$ & $2.0( \pm 1.1)$ & .33 \\
\hline Mean no. of prior lifetime adenomas $( \pm S D$ ) & 2871 & $2.5( \pm 2.6)$ & $4.3( \pm 3.9)$ & .02 \\
\hline One or more adenomas $\geq 1.0 \mathrm{~cm}$ at qualifying examination & 2915 & $879(30.4)$ & $11(42.3)$ & .20 \\
\hline
\end{tabular}

${ }^{*} \mathrm{n}$ varies because of missing data for some items. 
cancers were found during a reported 14,211 personyears of follow-up (0.4 cancers/1000 person-years), a rate comparable to that reported from the NPS. However, only $74 \%$ of patients in the Italian study had total colonic evaluation in the first follow-up period and only $14 \%$ of subjects ended follow-up with a complete colonoscopy.

A diagnosis of cancer soon after complete colonoscopy shows that the procedure is not $100 \%$ sensitive in identifying prevalent neoplasia. The high rate of cancer detection between the baseline examination and the year-1 colonoscopy (3.79 cancers/1000 person-years) as compared with the rate of cancer detection after the year-1 colonoscopy (0.96 cancers/1000 person-years) strongly suggests that prevalent neoplasia were missed at baseline. A study of back-to-back tandem colonoscopy reported a miss rate for adenomas $>1 \mathrm{~cm}$ of $6 \% .{ }^{19}$ Similarly, in a recent study of virtual colonoscopy, conventional colonoscopy failed to detect $12 \%$ of lesions $\geq 1 \mathrm{~cm}$, one of which was a cancer. ${ }^{20}$

It is also possible that some of the adenomas found before study enrollment were incompletely excised. This explanation seems plausible for the 5 invasive cancers diagnosed in a colonic segment where a large adenoma had been removed on the prior colonoscopy. Notably, 890 subjects had at least one baseline adenoma removed that was $>1 \mathrm{~cm}$. Therefore, while a few cancers may have occurred after incomplete polypectomy, the vast majority of large adenomas were effectively removed.

A third possibility is that some patients experienced a rapid transition from a small adenoma to a carcinoma or that there was de novo cancer formation. The adenoma/ carcinoma sequence varies for a given adenoma, and small flat cancers of the colon have been found. ${ }^{21,22}$ In one study using dye-assisted colonoscopy, 23\% of 211 American patients were found to have flat and depressed lesions of the colon. These lesions were more likely to be adenomatous and contain invasive cancer than their commonly recognized polypoid counterparts. ${ }^{23}$

Our finding that increasing number of lifetime adenomas is associated with subsequent development of advanced neoplasms is consistent with prior studies showing that adenoma multiplicity is a risk factor for subsequent recurrence of adenomas ${ }^{24-27}$ and cancer. ${ }^{28,29}$ These results support current guidelines that recommend earlier surveillance colonoscopy for patients found to have multiple adenomas at endoscopy. ${ }^{30,31}$ Other investigators $^{28,29}$ have reported that large adenomas are a risk factor for subsequent development of cancer and our data are consistent with this association, although the result was not statistically significant.
Perhaps the most intriguing implication of our findings relates to the true effectiveness of colonoscopy in prevention of colorectal cancer. A report from the NPS, based on follow-up of 1418 patients randomly assigned to 2 different schedules of surveillance colonoscopy, has often been taken to be the benchmark in this regard and has served as an important source of efficacy estimates for several cost-effectiveness analyses. ${ }^{7,32}$ The $76 \%$ reduction in cancer incidence that is widely cited as representing the effectiveness of colonoscopy derives from a comparison of cancer incidence among NPS participants with SEER incidence data (standardized incidence ratio, 0.24). To provide a context for our findings, we also report a standardized incidence ratio for our population compared with SEER (standardized incidence ratio, 0.98) but found the incidence in our population to be similar to expectation.

It is important to note that the comparison between a population under adenoma surveillance and the general population represented by SEER is problematic for a number of reasons. On the one hand, one might expect our observed rates to be higher than population rates. All of our patients had at least one previous adenoma and therefore are at higher risk for high-grade dysplasia and cancer than the general population, and some subjects had many previous adenomas. Moreover, unlike the general population, virtually all of our subjects had complete endoscopic follow-up, leading to detection of asymptomatic lesions. However, other factors would lead one to expect a much lower incidence of cancer in our studies than in SEER. Most importantly, all of our patients had undergone a recent complete colonoscopy and were deemed free of cancer (and adenoma) at the start of follow-up. Their subsequent cancer risk, therefore, cannot be readily compared with that of a general population group, in which most new cancer diagnoses pertain to tumors that have been present but unrecognized for years.

Considerations such as these make any comparison with SEER problematic for a quantitative estimate of the effectiveness of colonoscopic surveillance. A valid estimate of the efficacy of colonoscopy would require a randomized trial with controls who are either unscreened or receive an alternative, well-characterized screening procedure. Practical and ethical concerns probably preclude conducting such a study, so estimates of efficacy using data such as ours are likely to be based on substantial modeling assumptions that are not readily verifiable, such as the duration of the low risk conferred by being cancer-free at baseline.

It is important to note that the biases, which prevent valid comparison of our cancer incidence with population 
rates, also lead us to expect earlier-stage colorectal cancer than in the general population. Indeed, 16 of our 19 cancers $(84 \%)$ were confined to the bowel with no evidence of local node involvement, and none of our cancer cases had evidence of distant metastases. By comparison, in SEER registry data from 1992 to 1997, only 37\% of colorectal cancer cases were localized and $20 \%$ were metastatic at the time of diagnosis. ${ }^{33}$ Thus, our data are consistent with a benefit of colonoscopic surveillance with regard to the occurrence of advanced cancers, although the magnitude of this benefit is not clear.

The strengths of our study are its size and breadth. Recruitment for the trials used a large number of endoscopists, both university and private practice, from across North America. Presumably, our experience is generalizable to the broad spectrum of clinical practice. Histologic assessment of outcome was uniform, with utilization of a single study pathologist to confirm all adenomas and cancers. Follow-up of the subjects enrolled in the trials both clinically and endoscopically was essentially complete, limiting the potential for missing any important outcomes.

While the size of the study was large, the number of cancers and adenomas with high-grade dysplasia included in our analyses is relatively small, thus limiting our ability to identify risk factors for cancer and/or high-grade dysplasia. Because of the small number of these outcomes, statistical testing of risk factors was limited to simple comparisons of means or proportions with no regression or other modeling done. A second limitation of our study pertains to the completeness of our baseline examinations. For study enrollment, we relied on the endoscopist to indicate that the colonoscopy was adequate to completely visualize the colorectal mucosa and that the large bowel was free of lesions after the procedure. The study protocol did not require photodocumentation of cecal landmarks, and so it remains possible that some baseline examinations were incomplete.

Colorectal cancer occurs more frequently after complete colonoscopy than may be generally appreciated. Although these tend to be early lesions, informed consent for this procedure should probably mention this risk, as recently recommended by a multidisciplinary task force. ${ }^{34}$ Patients with a history of adenoma are a high-risk population for the development of colorectal cancer; although clinical trials ${ }^{27}$ have addressed some key issues regarding the appropriate schedule of colonoscopic surveillance in these patients, much important work remains. For example, a better understanding of the factors that determine risk for subsequent cancer development will be important for tailoring surveillance rec- ommendations to individual patients following adenoma removal. Future studies, either pooling data from large cohorts or perhaps a trial, are essential.

\section{References}

1. Muller AD, Sonnenberg A. Prevention of colorectal cancer by flexible endoscopy and polypectomy. A case-control study of 32,702 veterans. Ann Intern Med 1995;123:904-910.

2. Newcomb PA, Storer BE, Morimoto LM, Templeton A, Potter JD. Long-term efficacy of sigmoidoscopy in the reduction of colorectal cancer incidence. J Natl Cancer Inst 2003;95:622-625.

3. Winawer SJ, Zauber AG, Ho MN, O’Brien MJ, Gottlieb LS, Sternberg SS, Waye JD, Schapiro M, Bond JH, Panish JF, et al. Prevention of colorectal cancer by colonoscopic polypectomy. The National Polyp Study Workgroup. N Engl J Med 1993;329:19771981.

4. Mandel JS. Sigmoidoscopy screening probably works, but how well is still unknown. J Natl Cancer Inst 2003;95:571-573.

5. Pignone M, Saha S, Hoerger T, Mandelblatt J. Cost-effectiveness analyses of colorectal cancer screening: a systematic review for the U.S. Preventive Services Task Force. Ann Intern Med 2002; 137:96-104.

6. Frazier AL, Colditz GA, Fuchs CS, Kuntz KM. Cost-effectiveness of screening for colorectal cancer in the general population. JAMA 2000;284:1954-1961.

7. Sonnenberg A, Delco F, Inadomi JM. Cost-effectiveness of colonoscopy in screening for colorectal cancer. Ann Intern Med 2000;133:573-584.

8. Sonnenberg A, Delco F. Cost-effectiveness of a single colonoscopy in screening for colorectal cancer. Arch Intern Med 2002; 162:163-168.

9. Baron JA, Beach M, Mandel JS, van Stolk RU, Haile RW, Sandler RS, Rothstein R, Summers RW, Snover DC, Beck GJ, Bond JH, Greenberg ER. Calcium supplements for the prevention of colorectal adenomas. Calcium Polyp Prevention Study Group [see comments]. N Engl J Med 1999;340:101-107.

10. Baron JA, Cole BF, Sandler RS, Haile RW, Ahnen D, Bresalier R, Mckeown-Eyssen G, Summers RW, Rothstein R, Burke CA, Snover DC, Church TR, Allen JI, Beach M, Beck GJ, Bond JH, Byers T, Greenberg ER, Mandel JS, Marcon N, Mott LA, Pearson $\mathrm{L}$, Saibil $\mathrm{F}$, van Stolk RU. A randomized trial of aspirin to prevent colorectal adenomas. N Engl J Med 2003;348:891-899.

11. Greenberg ER, Baron JA, Tosteson TD, Freeman DH Jr, Beck GJ, Bond JH, Colacchio TA, Coller JA, Frankl HD, Haile RW, et al. A clinical trial of antioxidant vitamins to prevent colorectal adenoma. Polyp Prevention Study Group. N Engl J Med 1994;331: 141-147.

12. Greene FL. American Joint Committee on Cancer. American Cancer Society. AJCC cancer staging manual. New York: SpringerVerlag, 2002.

13. Breslow NE, Day NE, International Agency for Research on Cancer. Statistical methods in cancer research. Lyon: International Agency for Research on Cancer, 1980.

14. Rosner B. Fundamentals of biostatistics. Pacific Grove, CA: Duxbury, 2000.

15. Pabby A, Schoen RE, Weissfeld JL, Burt R, Kikendall JW, Lance P, Shike M, Lanza E, Schatzkin A. Analysis of colorectal cancer occurrence during surveillance colonoscopy in the dietary Polyp Prevention Trial. Gastrointest Endosc 2005;61:385-391.

16. Alberts DS, Martinez ME, Roe DJ, Guillen-Rodriguez JM, Marshall JR, van Leeuwen JB, Reid ME, Ritenbaugh C, Vargas PA, Bhattacharyya AB, Earnest DL, Sampliner RE. Lack of effect of a highfiber cereal supplement on the recurrence of colorectal adenomas. Phoenix Colon Cancer Prevention Physicians' Network. N Engl J Med 2000;342:1156-1162. 
17. Jorgensen OD, Kronborg O, Fenger C. The Funen Adenoma Follow-up Study. Incidence and death from colorectal carcinoma in an adenoma surveillance program. Scand J Gastroenterol 1993; 28:869-874.

18. Citarda F, Tomaselli G, Capocaccia R, Barcherini S, Crespi M. Efficacy in standard clinical practice of colonoscopic polypectomy in reducing colorectal cancer incidence. Gut 2001;48:812-815.

19. Rex DK, Cutler CS, Lemmel GT, Rahmani EY, Clark DW, Helper DJ, Lehman GA, Mark DG. Colonoscopic miss rates of adenomas determined by back-to-back colonoscopies. Gastroenterology 1997;112:24-28.

20. Pickhardt PJ, Choi JR, Hwang I, Butler JA, Puckett ML, Hildebrandt HA, Wong RK, Nugent PA, Mysliwiec PA, Schindler WR. Computed tomographic virtual colonoscopy to screen for colorectal neoplasia in asymptomatic adults. N Engl J Med 2003;349:21912200.

21. Rembacken BJ, Fujii T, Cairns A, Dixon MF, Yoshida S, Chalmers DM, Axon AT. Flat and depressed colonic neoplasms: a prospective study of 1000 colonoscopies in the UK. Lancet 2000;355: 1211-1214.

22. Hurlstone DP, Cross SS, Adam I, Shorthouse AJ, Brown S, Sanders DS, Lobo AJ. A prospective clinicopathological and endoscopic evaluation of flat and depressed colorectal lesions in the United Kingdom. Am J Gastroenterol 2003;98:2543-2549.

23. Saitoh Y, Waxman I, West AB, Popnikolov NK, Gatalica Z, Watari J, Obara T, Kohgo Y, Pasricha PJ. Prevalence and distinctive biologic features of flat colorectal adenomas in a North American population. Gastroenterology 2001;120:1657-1665.

24. Noshirwani KC, van Stolk RU, Rybicki LA, Beck GJ. Adenoma size and number are predictive of adenoma recurrence: implications for surveillance colonoscopy. Gastrointest Endosc 2000;51: 433-437.

25. van Stolk RU, Beck GJ, Baron JA, Haile R, Summers R. Adenoma characteristics at first colonoscopy as predictors of adenoma recurrence and characteristics at follow-up. The Polyp Prevention Study Group. Gastroenterology 1998;115:13-18.

26. Kronborg O, Hage E, Adamsen S, Deichgraeber E. Follow-up after colorectal polypectomy. I. A comparison of the effectiveness of repeated examinations of the colon every 6 and 24 months after removal of stalked polyps. Scand J Gastroenterol 1983;18: 1089-1093.
27. Winawer SJ, Zauber AG, O'Brien MJ, Ho MN, Gottlieb L, Sternberg SS, Waye JD, Bond J, Schapiro M, Stewart ET, et al. Randomized comparison of surveillance intervals after colonoscopic removal of newly diagnosed adenomatous polyps. The National Polyp Study Workgroup. N Engl J Med 1993;328:901-906.

28. Atkin WS, Morson BC, Cuzick J. Long-term risk of colorectal cancer after excision of rectosigmoid adenomas. N Engl J Med 1992;326:658-662.

29. Lotfi AM, Spencer RJ, IIstrup DM, Melton LJ III. Colorectal polyps and the risk of subsequent carcinoma. Mayo Clin Proc 1986;61: 337-343.

30. Winawer S, Fletcher R, Rex D, Bond J, Burt R, Ferrucci J, Ganiats T, Levin T, Woolf S, Johnson D, Kirk L, Litin S, Simmang C. Colorectal cancer screening and surveillance: clinical guidelines and rationale - update based on new evidence. Gastroenterology 2003;124:544-560.

31. Bond JH. Polyp guideline: diagnosis, treatment, and surveillance for patients with colorectal polyps. Practice Parameters Committee of the American College of Gastroenterology. Am J Gastroenterol 2000;95:3053-3063.

32. Lewis JD, Brown A, Localio AR, Schwartz JS. Initial evaluation of rectal bleeding in young persons: a cost-effectiveness analysis. Ann Intern Med 2002;136:99-110.

33. SEER Cancer Statistic Review, 1973-1988. In: Ries L, Eisner M, Kosary C, Hankey B, Miller B, Clegg L, Edwards BK, eds. Bethesda, MD: National Cancer Institute, 2001.

34. Rex DK, Bond JH, Winawer S, Levin TR, Burt RW, Johnson DA, Kirk LM, Litlin S, Lieberman DA, Waye JD, Church J, Marshall JB, Riddell RH. Quality in the technical performance of colonoscopy and the continuous quality improvement process for colonoscopy: recommendations of the U.S. Multi-Society Task Force on Colorectal Cancer. Am J Gastroenterol 2002;97:1296-1308.

Received November 1, 2004. Accepted March 23, 2005.

Address requests for reprints to: Douglas J. Robertson, MD, MPH, Section of Gastroenterology (111E), White River Junction VA Medical Center, 215 North Main Street, White River Junction, Vermont 05009. e-mail: douglas.robertson@med.va.gov; fax: (802) 296-6412.

Supported by a development award from the Foundation for Digestive Health and Nutrition. The parent studies were supported by grants CA 23108, CA46927, and CA 59005 from the National Institutes of Health. 